\title{
Atypical Papanicolaou Smear in Pregnancy
}

\author{
Thomas P. Connolly, DO and A. C. Evans, MD, PhD
}

Atypical glandular cells (AGC) in Papanicolaou (Pap) smears can be associated with premalignant and malignant cervical and endometrial lesions. AGC is difficult to diagnose in pregnancy due to confusion with normal cellular changes that accompany graviditas. While guidelines have been established for management of AGC cases in the non-pregnant patient, special considerations are required when this is discovered during a pregnancy. A routine Pap smear performed on a 29-year-old woman being seen for a history of infertility yielded AGC and a high-grade squamous intraepithelial lesion. The patient achieved pregnancy I month later. Satisfactory colposcopic exam was performed with cytobrush sampling of the endocervical canal, in addition to 2 exocervical biopsies at II weeks gestation. Positive diagnosis of endocervical adenocarcinoma in situ resulted in a risk-informed decision to proceed with a cold knife conization of the cervix. Final pathology showed complete resection of the lesion with negative margins and an additional area of squamous dysplasia (cervical intraepithelial neoplasia, grade II to III). Appropriate follow-up was recommended. AGC found upon Pap smear during a pregnancy can be associated with significant pathology for which an aggressive management approach is warranted.

Keywords: Pregnancy; Cervical intraepithelial neoplasia;Vaginal smear; Squamous cell carcinoma; Precancerous conditions

Reprint Requests:

Thomas P. Connolly, DO

Department of Obstetrics and Gynecology

Marshfield Clinic-Wausau Center

2727 Plaza Drive

Wausau, WI 5440 I

Telephone: 7|5-847-319|

Fax: 715-389-3808

Email: connolly.thomas@mashfieldclinic.org
Received: June 29, 2004

Resubmitted: November 8, 2004

Revised: December 9, 2004

Accepted: December 14, 2004 apanicolaou (Pap) smears that contain atypical squamous cells of undetermined significance can be followed up with repeat smears. However, those that contain atypical glandular cells (AGC) are more likely to be associated with severe underlying conditions and, therefore, warrant particular attention. ${ }^{1}$ The diagnosis of AGC by pathologists is difficult as there is a high degree of interobserver variation. ${ }^{2-7} \mathrm{Up}$ to $50 \%$ of women with AGC have significant histologic abnormalities, and cancer is present in $19.5 \%$ of women with AGC. ${ }^{1-3,8-13}$ In women younger than 35 years of age, cervical adenocarcinomas are increasing. 1,14,15 The National Cancer Institute, American Society of Colposcopy and Cervical Pathology, American College of Obstetricians and Gynecologists, and Centers for Disease Control recommend immediate diagnostic work-up and treatment in AGC cases. ${ }^{15-23}$ However, how to proceed with AGC in pregnancy has received limited discussion.

\section{Case Report}

This study was approved by the Institutional Review Board of Marshfield Clinic Research Foundation. A 29-year-old white woman (gravida 2, para 0, abortus 1) had a Pap smear diagnosis of AGC and high-grade squamous intraepithelial lesion (figure 1). The pathologist made a recommendation for colposcopy with endocervical biopsy. One month later the patient had a positive pregnancy test.

The patient denied use of tobacco, alcohol or drugs, and had no history of abnormal Pap smears, gynecologic surgery, or sexually transmissible diseases. 


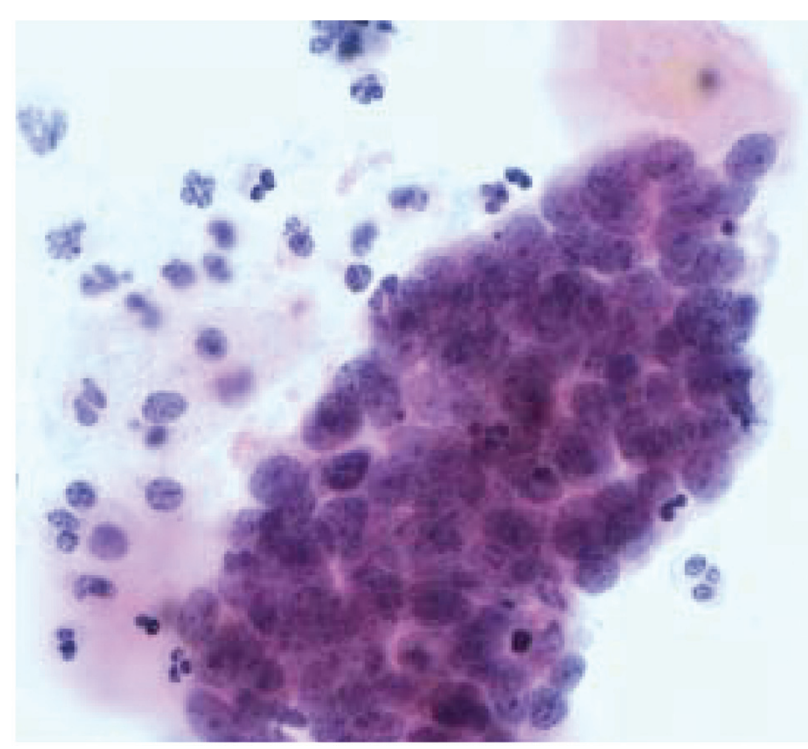

Figure 1. High grade squamous intraepithelial lesion (squamous carcinoma in situ) on Pap smear (Papanicolaou stain, x400).

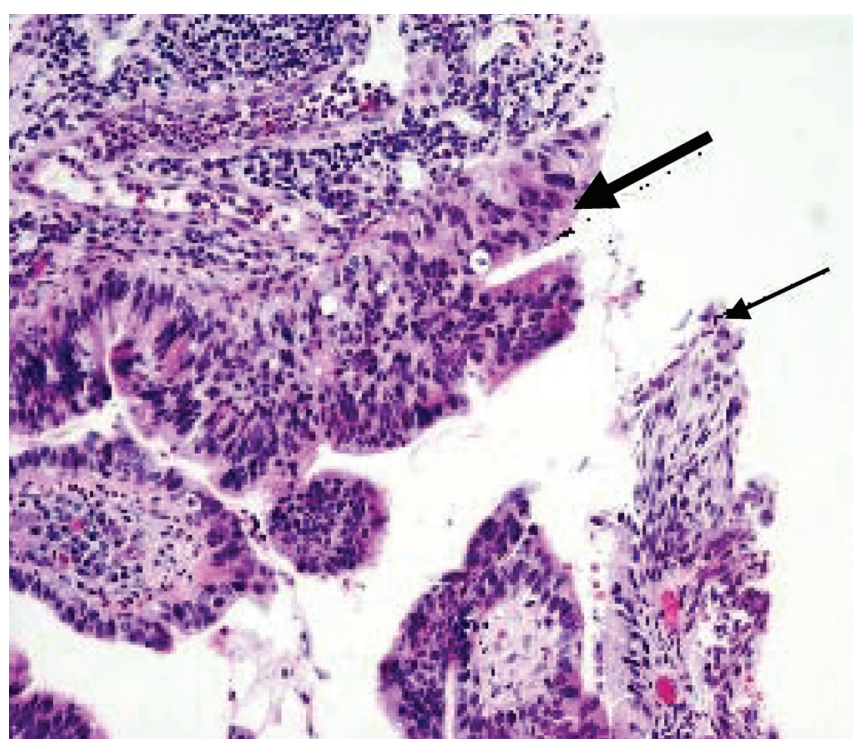

Figure 2. Cervical biopsy showing endocervical adenocarcinoma in situ (thick arrow) and adjacent severe squamous dysplasia (CIN III) (thin arrow) (H\&E, x200).

She had no family history of breast, colon, or gynecologic cancer. The patient had a 2-year history of infertility (oligomenorrheic with irregular menses).

Sixteen months earlier the patient was evaluated for abdominal pain and discomfort related to menses. Pelvic examination was negative. Abdominal computerized tomography, ultrasound, and Pap were all normal. Five months prior to the current pregnancy, the patient was treated with metronidazole gel for bacterial vaginosis. At the time of abnormal Pap diagnosis, the patient was using vaginal progesterone suppositories for infertility.

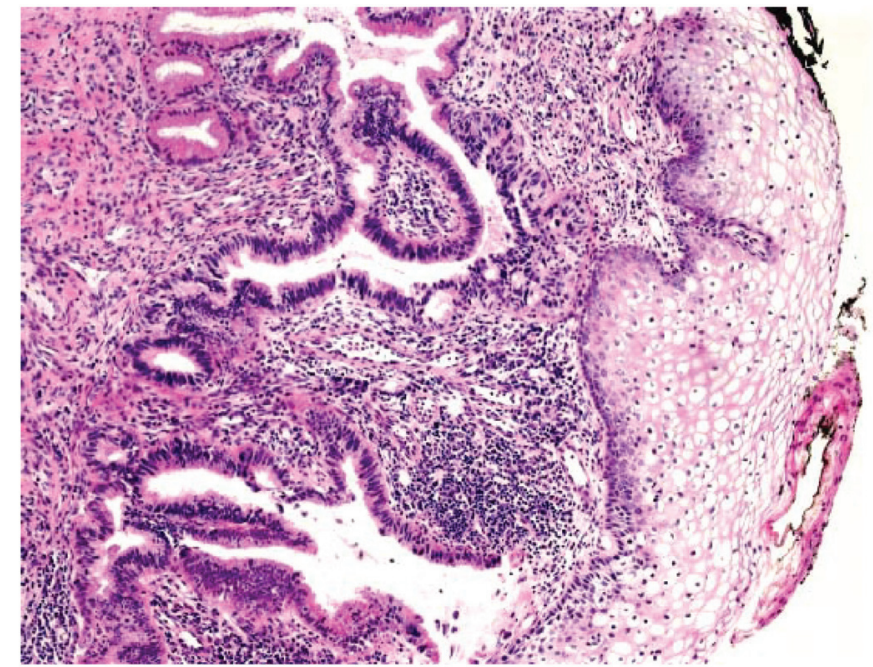

Figure 3. Residual endocervical adenocarcinoma in situ on the cone biopsy with focal severe squamous dysplasia (CIN III) and negative margins (H\&E, x100).

In addition to 2 exocervical biopsies at the transformation zone, a colposcopy was performed with cytobrush sampling of the endocervical canal (figure 2). Biopsies showed dysplastic endocervical epithelium with adenocarcinoma in situ (AIS) and areas of severe squamous dysplasia (CIN III). Additional Pap smear review revealed high-grade squamous intraepithelial neoplasia and atypical endocervical cells favoring adenocarcinoma. No features diagnostic of frankly invasive disease were found.

Cold knife conization of the cervix was performed at 11 weeks gestation. Pathology of the conization specimen showed complete excision with AIS involving endocervical glands and focal moderate to severe squamous dysplasia (CIN II to III) (figure 3). Ultrasound showed normal fetal activity and a normal amount of amniotic fluid.

Pap smears at 28 and 36 weeks gestation and postpartum were normal. The patient was advised to avoid another pregnancy until she had at least two normal Pap smears after delivery.

\section{Discussion}

Our case showed evidence of both squamous cell abnormalities and AGC. According to the 2001 Consensus Guidelines for the Management of Women with Cervical Cytological Abnormalities, ${ }^{24}$ nearly half the patients with biopsy-confirmed AIS have a coexisting squamous abnormality and, therefore, the presence of a coexisting squamous abnormality does not change the management of women with AGC or AIS. ${ }^{21,24-26}$ AGC is a significant indicator of more serious lesions, such as high-grade preinvasive squamous disease, AIS, and invasive adenocarcinoma. 1-3,8-16 This case illustrates that AGC found upon Pap smear during 


\section{Management of AGC in Pregnancy}

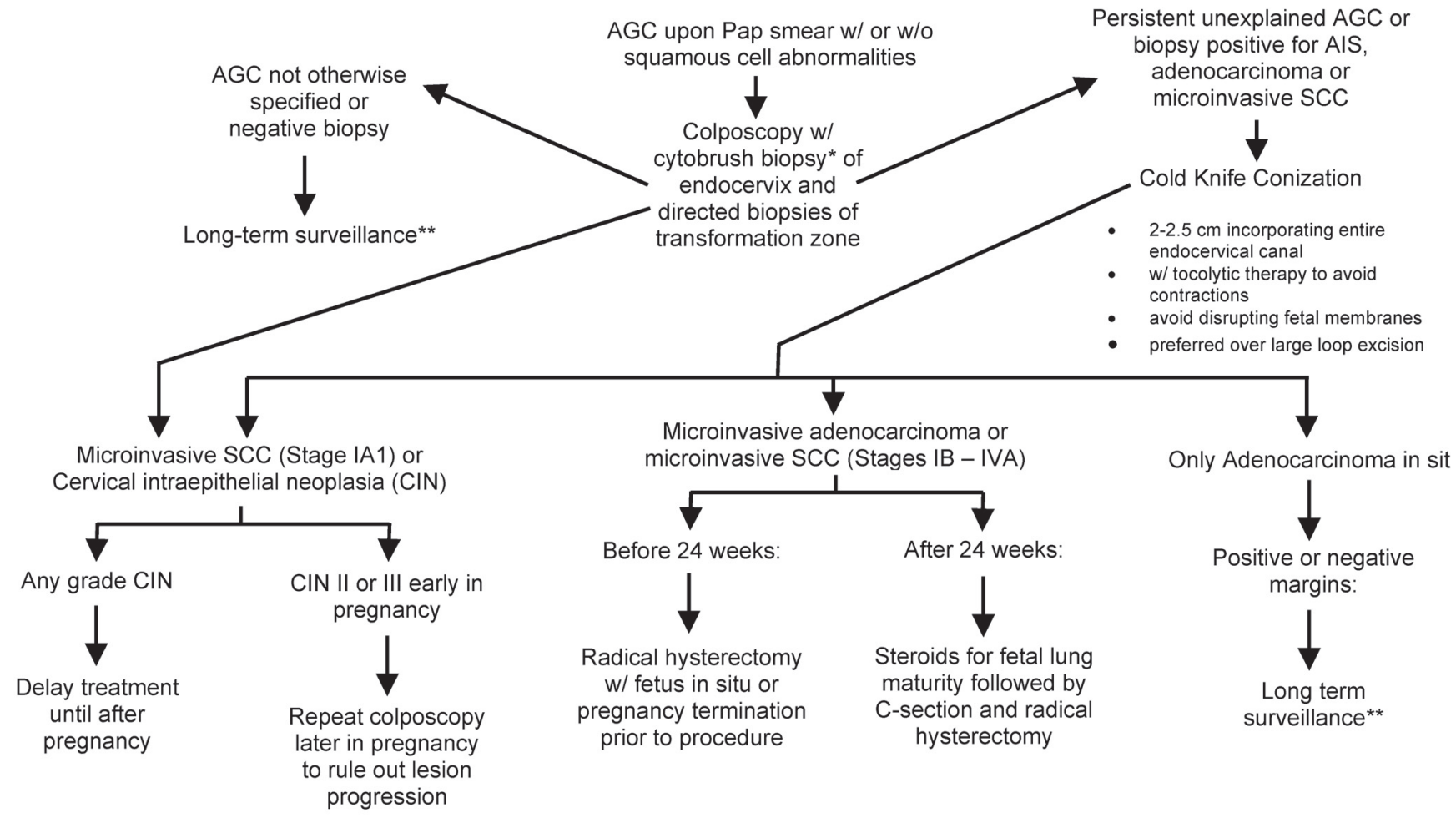

*Endocervical curettage (ECC) not possible in pregnancy.

${ }^{* *}$ Long-term surveillance: repeat Pap smear every 4-6 mo until 4 normals obtained, then annually.

Figure 4. Algorithm for management of atypical glandular cells (AGC) in pregnancy.

a pregnancy can be associated with significant pathology for which an aggressive management approach is warranted.

The Bethesda system classifies AGC as "glandular cells that demonstrate nuclear atypia appearing to exceed reactive or reparative changes but lacking unequivocal features of adenocarcinoma." 27 AGC interpretations span from benign, originating in endometrial, endocervical or unqualified sources, to favor neoplasia indicating suspicion for AIS or adenocarcinoma. ${ }^{28}$

Identifying AGC in pregnancy is particularly difficult. $10,29,30$ Cytologic changes associated with pregnancy and the postpartum period, endocervical gland hyperplasia, and/or Arias-Stella reaction, are benign findings that may be misidentified as in situ or invasive endocervical adenocarcinoma. Use of the cytobrush may falsely increase reports of AGC, but the ability to provide a rapid initial interpretation is an advantage. ${ }^{31}$ If known, the pathologist must be informed of the pregnancy status of the patient. The Arias-Stella reaction has been described as early as 22 days after the last menstrual period.
Following a confirmatory reading of AGC on the cervical smear, colposcopy with directed biopsy and endocervical curettage (ECC) are indicated in standard guidelines. ${ }^{14,16}$ Colposcopically directed biopsy is safe and reliable in evaluating pregnant patients with AGC, 32 but ECC cannot be performed in pregnancy. Alternatively, the cytobrush can be used (figure 4).

If the colposcopy with directed biopsy is negative with an initial Pap reading of AGC not otherwise specified, a Pap smear must be repeated every 4 to 6 months until four normals have been obtained, and then annually. If there is persistent, unexplained AGC or biopsy positive for AIS, adenocarcinoma, or microinvasive SCC, a cone biopsy is necessary.

A conization is required, unless cancer is diagnosed, if the colposcopy is negative and the initial Pap smear favors neoplasia. The rate of positive margins or recurrence for cervical AIS is significantly less when a cold knife conization is performed as opposed to a large loop excision 
of the transformation zone. ${ }^{21} \mathrm{~A}$ narrow cone incorporating the entire endocervical canal $(2.0 \mathrm{~cm}$ to $2.5 \mathrm{~cm})$ should be carefully performed to avoid disrupting the endometrium or fetal membranes. $1,9,12,14,16,33,34$

For conization under either spinal or general anesthesia, tocolytic therapy with nonsteroidal anti-inflammatory agents should be used to prevent contractions. Risks of cone biopsy specific to pregnancy include preterm labor, miscarriage, bleeding, premature rupture of membranes, and chorioamnionitis. A large biopsy could result in cervical stenosis or cervical incompetence. ${ }^{35}$

Squamous intraepithelial neoplasia and microinvasive squamous cell carcinoma can often be treated with cervical conization. Endocervical curettage should not be performed during pregnancy. Treatment for any grade CIN should be delayed until after pregnancy. If biopsy-proven CIN II or III are seen in early pregnancy, repeat colposcopy should be considered later in pregnancy to rule out lesion progression. $^{36-40}$ Multifocal adenocarcinoma is more challenging. Microinvasive adenocarcinoma may involve lymph node metastases and deeper invasion. Treatment involves radical hysterectomy with bilateral pelvic lymphadenectomies. In the pregnant patient, a radical hysterectomy with the fetus in situ, or pregnancy termination prior to the radical hysterectomy is recommended. After 24 weeks gestational age, steroids should be administered for fetal lung maturity followed by a Caesarean section and radical hysterectomy.

If only AIS is identified on a cone specimen and completely excised, close follow-up with regular Pap smears for the remainder of the pregnancy and then, every 4 months for 2 years and annually afterwards, is required. Where no evidence of invasion exists, no further treatment is needed. ${ }^{14,16,33,41}$ For patients with positive margins, no evidence exists that would indicate an advantage of repeat conization during pregnancy in an attempt to obtain clear margins. Negative margins, while promising in young women and if a $10 \mathrm{~mm}$ clear margin can be obtained, ${ }^{42,43}$ are no assurance of freedom from disease. ${ }^{44-47}$ Conversely, positive margins are not universally indicative of residual AIS. ${ }^{43}$ Some warn against a potential risk of overtreatment and causing unnecessary stress in the patient if further treatment is based solely on the status of the cone margins. ${ }^{48}$ Repeat conization might be warranted only if microinvasive disease or invasive carcinoma that would alter the timing of delivery were highly suspected. ${ }^{49}$ With clear, unevaluable, or positive margins, long-term surveillance is warranted for cervical AIS. ${ }^{50}$ In our case, the added presence of high grade squamous intraepithelial neoplasia (CIN III) is further reason for continuing surveillance in this patient. ${ }^{51}$

Women with AIS of the cervix treated with conization inconsistently have residual disease in the uterus, regardless of positive or negative margins. ${ }^{35,52-54}$ Ironically, many have residual disease that will remain clinically insignificant. ${ }^{1}$

\section{Conclusion}

Despite broad diagnostic parameters and low AGC incidence, significant disease can be found and treated early, and successfully, in both pregnant and non-pregnant patients. 6,16 With the incidence of this diagnosis increasing, the potential for continued impact on women's health is significant. While AGC subclassifications and treatment outcomes are studied, an aggressive management and surveillance approach is warranted in both pregnant and non-pregnant patients. ${ }^{1}$

\section{Acknowledgments}

The authors wish to thank Marshfield Clinic Research Foundation for providing assistance in the preparation of this manuscript through the services of Anne Nikolai, Graig Eldred, Alice Stargardt, and Linda Weis.

\section{References}

1. Kaferle JE, Malouin JM. Evaluation and management of the AGUS Papanicolaou smear. Am Fam Physician 2001;63:2239-2244

2. Eddy GL, Strumpf KB, Wojtowycz MA, Piraino PS, Mazur MT. Biopsy findings in five hundred thirty-one patients with atypical glandular cells of uncertain significance as defined by the Bethesda system. Am J Obstet Gynecol 1997; 177:1188-1195.

3. Raab SS, Bishop NS, Zaleski MS. Effect of cervical disease history on outcomes of women who have a pap diagnosis of atypical glandular cells of undetermined significance. Gynecol Oncol 1999;74:460-464.

4. Massad LS, Collins YC, Meyer PM. Biopsy correlates of abnormal cervical cytology classified using the Bethesda system. Gynecol Oncol 2001;82:516-522.

5. Reuss E, Price J, Koonings P. Atypical glandular cells of undetermined significance. Subtyping as a predictor of outcome. J Reprod Med 2001;46:701-705.

6. Nasuti JF, Fleisher SR, Gupta PK. Atypical glandular cells of undetermined significance (AGUS): clinical considerations and cytohistologic correlation. Diagn Cytopathol 2002;26:186-190.

7. Raab SS. Can glandular lesions be diagnosed in pap smear cytology? Diagn Cytopathol 2000;23:127-133.

8. Veljovich DS, Stoler MH, Andersen WA, Covell JL, Rice LW. Atypical glandular cells of undetermined significance: a five-year retrospective histopathologic study. Am J Obstet Gynecol 1998;179:382-390.

9. Zweizig S, Noller K, Reale F, Collis S, Resseguie L. Neoplasia associated with atypical glandular cells of undetermined significance on cervical cytology. Gynecol Oncol 1997;65:314-318

10. Chhieng DC, Elgert P, Cangiarella JF, Cohen JM. Significance of AGUS Pap smears in pregnant and postpartum women. Acta Cytol 2001;45:294-299.

11. Goff BA, Atanasoff P, Brown E, Muntz HG, Bell DA, Rice LW. Endocervical glandular atypia in Papanicolaou smears. Obstet Gynecol 1992;79:101-104.

12. Valdini A, Vaccaro C, Pechinsky G, Abernathy V. Incidence and evaluation of an AGUS Papanicolaou smear in primary care. J Am Board Fam Pract 2001;14:172-177.

13. Soofer SB, Sidawy MK. Atypical glandular cells of undetermined significance: clinically significant lesions and means of patient follow-up. Cancer 2000;90:207-214. 
14. Cox JT. Management of atypical squamous cells of undetermined significance and low-grade squamous intra-epithelial lesion by human papillomavirus testing. Best Pract Res Clin Obstet Gynaecol 2001;15:715-741.

15. Minnesota Department of Health (MDH), Minnesota Breast and Cervical Cancer Control Program (MBCCCP). Evaluation and management of abnormal pap smears: a primer for primary care providers. Available at: http://www.health.state.mn.us/divs/hpcd/ccs/mbcccp/cprimer. pdf. Accessed January 7, 2004.

16. Levine L, Lucci JA 3rd, Dinh TV. Atypical glandular cells: new Bethesda Terminology and Management Guidelines. Obstet Gynecol Surv 2003;58:399-406.

17. Mattosinho de Castro Ferraz Mda G, Focchi J, Stavale JN, Nicolau SM, Rodrigues de Lima G, Baracat EC. Atypical glandular cells of undetermined significance. Cytologic predictive value for glandular involvement in high grade squamous intraepithelial lesions. Acta Cytol 2003;47:154-158.

18. Cook-Glenn CL, Keyhani-Rofagha S. Adenocarcinoma of the uterine cervix associated with pregnancy: a retrospective 10-year investigative study. Diagn Cytopathol 1998;18:393-397.

19. Meath AJ, Carley ME, Wilson TO. Atypical glandular cells of undetermined significance. Review of final histologic diagnoses. J Reprod Med 2002;47:249-252.

20. Hammoud MM, Haefner HK, Michael CW, Ansbacher R. Atypical glandular cells of undetermined significance. Histologic findings and proposed management. J Reprod Med 2002;47:266-270.

21. Widrich T, Kennedy AW, Myers TM, Hart WR, Wirth S. Adenocarcinoma in situ of the uterine cervix: management and outcome. Gynecol Oncol 1996;61:304-308.

22. Davis JR, Moon LB. Increased incidence of adenocarcinoma of uterine cervix. Obstet Gynecol 1975;45:79-83.

23. Mitchell H, Medley G, Gordon I, Giles G. Cervical cytology reported as negative and risk of adenocarcinoma of the cervix: no strong evidence of benefit. Br J Cancer 1995; 71:894-897.

24. Wright TC Jr, Cox JT, Massad LS, Twiggs LB, Wilkinson EJ; ASCCP-Sponsored Consensus Conference. 2001 consensus guidelines for the management of women with cervical cytological abnormalities. JAMA 2002;287:2120-2129.

25. Ostor AG, Duncan A, Quinn M, Rome R. Adenocarcinoma in situ of the uterine cervix: an experience with 100 cases. Gynecol Oncol 2000;79:207-210.

26. Muntz HG, Bell DA, Lage JM, Goff BA, Feldman S, Rice LW. Adenocarcinoma in situ of the uterine cervix. Obstet Gynecol 1992;80:935-939.

27. Solomon D, Davey D, Kurman R, Moriarty A, O'Connor D, Prey M, Raab S, Sherman M, Wilbur D, Wright T Jr, Young N; Forum Group Members; Bethesda 2001 Workshop. The 2001 Bethesda system. Terminology for reporting results of cervical cytology. JAMA 2002;287:2114-2119.

28. Apgar BS, Zoschnick L, Wright TC Jr. The 2001 Bethesda system terminology. Am Fam Physician 2003;68:1992-1998.

29. Benedet JL, Selke PA, Nickerson KG. Colposcopic evaluation of abnormal Papanicolaou smears in pregnancy. Am J Obstet Gynecol 1987;157:932-937.

30. Pisharodi LR, Jovanoska S. Spectrum of cytologic changes in pregnancy. A review of 100 abnormal cervicovaginal smears, with emphasis on diagnostic pitfalls. Acta Cytol 1995;39:905-908.

31. Economos K, Perez Veridiano N, Delke I, Collado ML, Tancer ML. Abnormal cervical cytology in pregnancy: a 17-year experience. Obstet Gynecol 1993;81:915-918.

32. Biscotti CV, Gero MA, Toddy SM, Fischler DF, Easley KA. Endocervical adenocarcinoma in situ: an analysis of cellular features. Diagn Cytopathol 1997;17:326-332.

33. Connor JP. Noninvasive cervical cancer complicating pregnancy. Obstet Gynecol Clin North Am 1998;25:331-342.
34. Jones HW $3^{\text {rd }}$. Clinical treatment of women with atypical squamous cells of undetermined significance or atypical glandular cells of undetermined significance cervical cytology. Clin Obstet Gynecol 2000;43:381-393.

35. Poynor EA, Barakat RR, Hoskins WJ. Management and follow-up of patients with adenocarcinoma in situ of the uterine cervix. Gynecol Oncol 1995;57:158-164.

36. Jain AG, Higgins RV, Boyle MJ. Management of low-grade squamous intraepithelial lesions during pregnancy. Am J Obstet Gynecol 1997; 177:298-302.

37. National Comprehensive Cancer Network Practice Guidelines in Oncology. Cervical screening. Version 1.2004. Available at: http://www.nccn.org/professionals/physician_gls/PDF/cervic al_screening.pdf. Accessed 09/30/04.

38. Rosen A, Klein M, Vavra N, Gitsch G, Karasegh S, Schrock A, Stiegelbauer M, Romig S. Pap IV in pregnancy-a retrospective multicenter study. Geburtshilfe Frauenheilkd 1991;51:208-210.

39. Patsner B. Management of low-grade cervical dysplasia during pregnancy. South Med J 1990;83:1405-1406, 1412.

40. Schindler EM, Brielmaier M, Schindler AE. Atypical cytologic findings in pregnancy. Geburtshilfe Frauenheilkd 1993;53:483-487.

41. Cullimore JE, Luesley DM, Rollason TP, Byrne P, Buckley $\mathrm{CH}$, Anderson M, Williams DR, Waddell C, Hudson E, Shafi MI. A prospective study of conization of the cervix in the management of cervical intraepithelial glandular neoplasia (CIGN) - a preliminary report. Br J Obstet Gynaecol 1992;99:314-318.

42. Shin CH, Schorge JO, Lee KR, Sheets EE. Conservative management of adenocarcinoma in situ of the cervix. Gynecol Oncol 2000;79:6-10.

43. Goldstein NS, Mani A. The status and distance of cone biopsy margins as a predictor of excision adequacy for endocervical adenocarcinoma in situ. Am J Clin Pathol 1998;109:727-732.

44. Im DD, Duska LR, Rosenshein NB. Adequacy of conization margins in adenocarcinoma in situ of the cervix as a predictor of residual disease. Gynecol Oncol 1995;59:179-182.

45. Azodi M, Chambers SK, Rutherford TJ, Kohorn EI, Schwartz PE, Chambers JT. Adenocarcinoma in situ of the cervix: management and outcome. Gynecol Oncol 1999;73:348-353.

46. Lea JS, Shin CH, Sheets EE, Coleman RL, Gehrig PA, Duska LR, Miller DS, Schorge JO. Endocervical curettage at conization to predict residual cervical adenocarcinoma in situ. Gynecol Oncol 2002;87:129-132.

47. Nagaishi M, Fujiwaki R, Hata K, Makihara K, Yamane Y, Miyazaki K. Adenocarcinoma in situ coexisting with carcinoma in situ of the cervix during pregnancy. Arch Gynecol Obstet 2004;270:116-118.

48. Andersen ES, Nielsen K. Adenocarcinoma in situ of the cervix: a prospective study of conization as definitive treatment. Gynecol Oncol 2002;86:365-369.

49. Douvier S, Filipuzzi L, Sagot P. Management of cervical intra-epithelial neoplasm during pregnancy. Gynecol Obstet Fertil 2003;31:851-855

50. Hwang DM, Lickrish GM, Chapman W, Colgan TJ. Long-term surveillance is required for all women treated for cervical adenocarcinoma in situ. Obstet Gynecol Surv 2004;59:659-660

51. Lin H, Chang HY, Huang CC, Changchien CC. Prediction of disease persistence after conization for microinvasive cervical carcinoma and cervical intraepithelial neoplasia grade 3. Int J Gynecol Cancer 2004;14:311-316.

52. Luesley DM, Jordan JA, Woodman CB, Watson N, Williams DR, Waddell C. A retrospective review of adenocarcinoma-in-situ and glandular atypia of the uterine cervix. Br J Obstet Gynaecol 1987;94:699-703. 
53. Wolf JK, Levenback C, Malpica A, Morris M, Burke T, Mitchell MF. Adenocarcinoma in situ of the cervix: significance of cone biopsy margins. Obstet Gynecol 1996;88:82-86

54. Denehy TR, Gregori CA, Breen JL. Endocervical curettage, cone margins, and residual adenocarcinoma in situ of the cervix. Obstet Gynecol 1997;90:1-6.

\section{Author Affiliations}

Thomas P. Connolly, DO, Department of Obstetrics and Gynecology, Marshfield Clinic-Wausau Center, 2727 Plaza

Drive, Wausau, WI 54401

A. C. Evans, MD, PhD, Division of Gynecologic Oncology, Department of Obstetrics and Gynecology, Marshfield Clinic, 1000 N. Oak Avenue, Marshfield, WI 54449. 